\title{
Cytotoxicity Evaluation of Four Endodontic Sealers
}

\author{
Paulo Tadeu da SILVA ${ }^{1}$ \\ Fernanda Geraldes PAPPEN ${ }^{1}$ \\ Erick Miranda SOUZA ${ }^{1}$ \\ João Eduardo DIAS ${ }^{2}$ \\ Idomeo BONETTI FILHO ${ }^{1}$ \\ Iracilda Zepponi CARLOS ${ }^{3}$ \\ Renato Toledo LEONARDO ${ }^{1}$ \\ ${ }^{1}$ Department of Restorative Dentistry, Dental School of Araraquara, \\ State University of São Paulo, Araraquara, SP, Brazil \\ ${ }^{2}$ Discipline of Endodontics, Dental School of Caparica, Portugal \\ ${ }^{3}$ Discipline of Immunology, School of Pharmaceutical Sciences of Araraquara, \\ State University of São Paulo, Araraquara, SP, Brazil
}

\begin{abstract}
This study evaluated in vitro the cytotoxicity of four root canal sealers (Topseal, EndoRez, TubliSeal and Kerr Pulp Canal Sealer E.W.T.) and their effects on reactive oxygen/nitrogen intermediate induction by mouse peritoneal macrophages. Thioglycollate-induced cells were obtained from Swiss mice by peritoneal lavage with $5 \mathrm{~mL} 10 \mathrm{mM}$ phosphate-buffered saline, washed twice and resuspended $\left(10^{6}\right.$ cells $\left./ \mathrm{mL}\right)$ in appropriate medium for each test. Cytotoxicity was determined by the presence of hydrogen peroxide $\left(\mathrm{H}_{2} \mathrm{O}_{2}\right)$ and nitric oxide (NO) by the peroxidase-dependent oxidation of phenol red and Griess reaction, respectively. Sealer suspensions were obtained in two different concentrations from each material: $18 \mathrm{mg} / \mathrm{mL}$ and $9 \mathrm{mg} / \mathrm{mL}$, established according to compatibility parameters following MTT assay. Comparing the sealers, $\mathrm{H}_{2} \mathrm{O}_{2}$ release at concentrations of $9 \mathrm{mg} / \mathrm{mL}$ and $18 \mathrm{mg} / \mathrm{mL}$ was similar: Topseal > positive control (medium + cells $+5 \mathrm{mg} / \mathrm{mL}$ zimozan solution) $>$ EndoRez $>$ TubliSeal $>$ Kerr Pulp E.W.T. $>$ negative control (medium + cells) NO release at concentration of $9 \mathrm{mg} / \mathrm{mL}$ was: positive control (medium + cells $+10 \mu \mathrm{g} / \mathrm{mL}$ LPS solution) > Topseal > Kerr Pulp E.W.T. $>$ TubliSeal $=$ EndoRez $>$ negative control (medium + cells); at concentration of $18 \mathrm{mg} / \mathrm{mL}$ was: positive control > Topseal $>$ Kerr Pulp E.W.T > TubliSeal > EndoRez > negative control. Based on the results, it may be concluded that Topseal presented the highest cytotoxicity among the tested sealers, releasing higher concentrations of $\mathrm{NO}$ and $\mathrm{H}_{2} \mathrm{O}_{2}$ in macrophage culture.
\end{abstract}

Key Words: cytotoxicity, root canal sealer, macrophages, nitric oxide, hydrogen peroxide.

\section{INTRODUCTION}

The goal of a root canal filling is to prevent coronal re-infection and entomb remaining bacteria (1) since the absence of root filling or presence of poor fillings may provide pathways for bacteria and toxins to the periapex. Additionally, root canal sealers must be biocompatible because they may be in direct contact with the apical connective tissues for a long period and might cause inflammatory degeneration of part of these tissues, delaying the periapical healing $(2,3)$. Sealing and biological properties of endodontic sealers are thus essential for the clinical success of endodontic therapy.
Root canal sealers can have different bases, and epoxy resins, calcium hydroxide, zinc-oxide eugenol (ZOE) and silicone present different biological characteristics. ZOE-based sealers have a long history of use, with good mechanical properties, but known cytotoxic effects due to eugenol release (4). Resin-based sealers are becoming more popular, but studies have indicated some toxic and mutagenic effects $(5,6)$.

Macrophages are widely distributed in different tissues and play an essential role in the development of the specific and nonspecific immune response. These cells can be activated by bacterial components, cytokines and chemicals. When activated, macrophages produce 
and release numerous secretory products like cytokines, inorganic reactive radicals, reactive oxygen intermediates (ROI) and reactive nitrogen intermediates (RNI), all having biological activity (7). Hydrogen peroxide $\left(\mathrm{H}_{2} \mathrm{O}_{2}\right)$ and nitric oxide (NO) are important in cell signaling and are effective molecules for the microbicidal and cytotoxic response of macrophages after stimulation (8). ROI and RNI can be considered as beneficial intermediates for presenting microbiocidal and tumoricidal activities. Otherwise, they can also be destructive for the host tissue under certain conditions (9).

This study evaluated in vitro the cytotoxicity of different endodontic sealers by the analysis of NO and $\mathrm{H}_{2} \mathrm{O}_{2}$ production by mouse peritoneal macrophages.

\section{MATERIAL AND METHODS}

Eleven Swiss mice weighting 18-25 $\mathrm{g}$ from the Animal House of the School of Pharmaceutical Sciences of Araraquara, Brazil were used in all experiments. All procedures were undertaken in accordance with the institutional Research Ethics Committee.

Thioglycollate-elicited peritoneal exudate cells (PECs) were obtained from Swiss mice following intraperitoneal injection of $3 \mathrm{~mL}$ of thioglycollate medium and rinsing of the peritoneal cavity with $5.0 \mathrm{~mL}$ of 10 $\mathrm{mM}$ phosphate buffered saline (PBS; pH 7.4; SigmaAldrich Brasil, São Paulo, SP, Brazil). The cells were washed twice with PBS by centrifugation at $200 \mathrm{x} g$ for $5 \mathrm{~min}$ at $4^{\circ} \mathrm{C}$ and resuspended in appropriate medium for each test. Macrophages $\left(2 \times 10^{6}\right.$ cells $\left./ \mathrm{mL}\right)$ were suspended in RPMI-1640 containing 5\% (v/v) heatinactivated fetal calf serum (FCS; Cutilab, Campinas, SP, Brazil), $100 \mathrm{IU} / \mathrm{mL}$ penicillin (Sigma-Aldrich Brasil), $100 \mu \mathrm{g} / \mathrm{mL}$ streptomycin (Sigma-Aldrich Brasil) and 50 mM 2-mercaptoethanol (Sigma-Aldrich Brasil).

Four endodontic sealers were evaluated: Topseal (epoxy-based; Dentsply De Trey, Konztanz, Germany), EndoRez (methacrylate-based; Ultradent Products, South Jordan, UT, USA), TubliSeal (ZOE-based; SybronEndo, Orange, CA, USA) and Kerr Pulp Canal Sealer E.W.T. (ZOE-based; Kerr Hawe, Bioggio, Switzerland). Materials were prepared as per manufacturers' instructions under aseptic conditions to prevent biological contamination during the cytotoxicity test. Sealer suspensions were made in polyethylene glycol 400 in two concentrations per material: $18 \mathrm{mg} / \mathrm{mL}$ and $9 \mathrm{mg} / \mathrm{mL}$. The suspensions were autoclaved for $20 \mathrm{~min}$ at $121^{\circ} \mathrm{C}$.
These concentrations were established according to compatibility parameters following the MTT assay.

\section{Analysis of Hydrogen Peroxide}

$\mathrm{H}_{2} \mathrm{O}_{2}$ was measured by the horseradish peroxidase (HRP)-dependent oxidation of phenol red (10). Macrophages $\left(2 \times 10^{6}\right.$ cells $\left./ \mathrm{mL}\right)$ were suspended in 10 $\mathrm{mM}$ potassium phosphate buffer containing $140 \mathrm{mM}$ $\mathrm{NaCl}, 5.5 \mathrm{mM}$ dextrose, $0.56 \mathrm{mM}$ phenol red, and 0.01 $\mathrm{mg} / \mathrm{mL}$ type II HRP, pH 7.4. $100 \mu \mathrm{L}$ of this suspension were added to each well of a 96-well tissue culture plate and exposed to $50 \mu \mathrm{L}$ of sealer suspension for $1 \mathrm{~h}$ at $37^{\circ} \mathrm{C}, 5 \% \mathrm{CO}_{2}$ atmosphere. The reaction was inactivated with $10 \mu \mathrm{L}$ of $4 \mathrm{~N} \mathrm{NaOH}$. The absorbances were read at $620 \mathrm{~nm}$. Results were expressed as nmol $\mathrm{H}_{2} \mathrm{O}_{2}$ per $2 \times 10^{5}$ cells as calibrated against solutions of known $\mathrm{H}_{2} \mathrm{O}_{2}$ concentration. The experiments were performed in triplicate. Each experiment was accompanied by a positive control (medium + cells $+5 \mathrm{mg} / \mathrm{mL}$ zimozan solution) and a negative control (medium + cells).

\section{Analysis of Nitric Oxide}

NO synthesis was determined by measuring the accumulation of nitrite $\left(\mathrm{NO}_{2}^{-}\right)$, a stable metabolite of $\mathrm{NO}$, in culture supernatants using the Griess reaction (11). Macrophages at $5 \times 10^{6}$ cells $/ \mathrm{mL}$ in RPMI-1640 (Sigma, St. Louis, MO, USA) containing 5\% heatinactivated FCS, $100 \mathrm{IU} /$ penicillin, $100 \mu \mathrm{g} / \mathrm{mL}$ streptomycin and $50 \mathrm{mM}$ 2-mercaptoethanol were added to each well of a 96-well tissue culture dish with $100 \mu \mathrm{L}$ of the sealer solution. The cells were incubated for 24 $\mathrm{h}$ (time for $\mathrm{NO}$ assay) at $37^{\circ} \mathrm{C}$ in a $5 \% \mathrm{CO}_{2}$ atmosphere. After incubation, $50 \mu \mathrm{L}$ aliquots of culture supernatant were mixed with $50 \mu \mathrm{L}$ of Griess reagent $(1 \% \mathrm{w} / \mathrm{v}$ sulphanylamide, $0.1 \% \mathrm{w} / \mathrm{v}$ naphthylethylenediamine and $3 \% \mathrm{H}_{3} \mathrm{PO}_{4}$ ), and incubated at room temperature for 10 min. Absorbance at $540 \mathrm{~nm}$ was measured using a microplate reader. $\mathrm{NO}_{2}$ - concentration $(\mu \mathrm{mol} / \mathrm{L})$ was calculated from a $\mathrm{NaNO}_{2}$ standard curve. Each experiment was accompanied by a positive control (medium + cells $+10 \mu \mathrm{g} / \mathrm{mL}$ LPS solution) and a negative control (medium + cells). The experiments were done in triplicate.

\section{Statistical Analysis}

Results are representative of three independent 
experiments and were presented as means \pm SEM of quadruplicate observations $(n=12)$. Data were analyzed statistically by the Student's t-test using the Origin software (OriginLab Corp., Northamptom, MA, USA).

\section{RESULTS}

The means were compared in pairs and analyzed by the Student's t-test. The statistical results of the mean release is summarized in the following lines. $\mathrm{H}_{2} \mathrm{O}_{2}$ release at concentrations of $9 \mathrm{mg} / \mathrm{mL}$ and $18 \mathrm{mg} / \mathrm{mL}$ was similar: Topseal > positive control > EndoRez > TubliSeal > Kerr Pulp E.W.T. > negative control. NO release at concentration of $9 \mathrm{mg} / \mathrm{mL}$ was: positive control $>$ Topseal > Kerr Pulp E.W.T. $>$ TubliSeal = EndoRez $>$ negative control; NO release at concentration of $18 \mathrm{mg} /$ mL was: positive control > Topseal > Kerr Pulp E.W.T > TubliSeal $>$ EndoRez $>$ negative control. (Figs. 1 and 2).

\section{DISCUSSION}

Macrophages have been used for immunocytotoxicity testing because they permit the measurement of the cytotoxic response directly in the cell culture and have the ability to maintain immunological functions in the presence of many different chemical agents (12). The effect of endodontic sealers on macrophage activity is of interest since these cells play a key role on innate and acquired immune defenses and on the pathogenesis of inflammation (13).

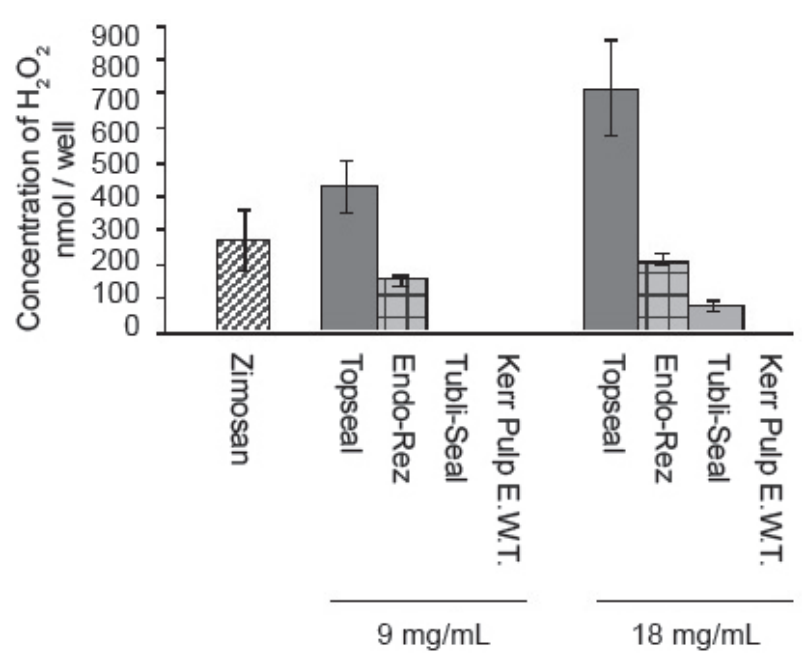

Figure 1. Graphic presentation of mean hydrogen peroxide release and the respective $95 \%$ range for the means.
In response to antigens or inflammatory signals generated at sites of tissue injury, macrophages undergo a process of cellular "activation" which is associated with morphological, functional, and biochemical changes in the cells. One prominent characteristic of activated macrophages is their increased capacity to release pro-inflammatory and cytotoxic mediators, which aid in antigen destruction (14).

In the present study, the determination of subtoxic concentrations of the sealers using the MTT assay permitted the measurement of the parameters and the exclusion of cell mortality as a variable.

The measurement of $\mathrm{H}_{2} \mathrm{O}_{2}$ and $\mathrm{NO}$ levels by colorimetric analysis allows, associated with other parameters, the understanding of the compatibility of the material with the host tissues (2). Under physiological conditions, $\mathrm{H}_{2} \mathrm{O}_{2}$ is generated in low levels and is quickly metabolized or degraded, but long exposures and high concentrations of $\mathrm{H}_{2} \mathrm{O}_{2}$ can destroy biological structures and lead to irreversible cell damage (15).

Both resin-based sealers (Topseal and EndoRez) required more energy to be phagocytized, what was expressed by the amount of $\mathrm{H}_{2} \mathrm{O}_{2}$ released. This indicates that these sealers are more cytotoxic than TubliSeal and Kerr Pulp Canal Sealer E.W.T., respectively. Topseal induced higher levels of NO release than Kerr Pulp Canal Sealer E.W.T., TubliSeal and EndoRez, respectively. NO affects virtually every step of the development of inflammation. Large amounts of NO can be toxic and pro-inflammatory. NO is not a strong oxidant. However,

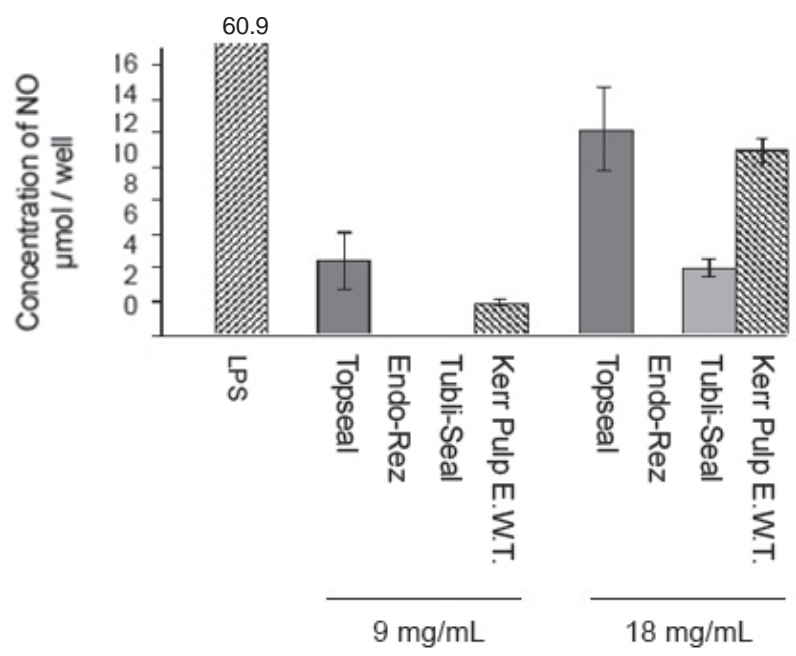

Figure 2. Graphic presentation of mean nitric oxide release and the respective $95 \%$ range for the means. 
it reacts at a nearly diffusion limited rate with superoxide to form peroxynitrite, which is a strong oxidant. Peroxynitrite is formed by activated inflammatory cells and agonist-stimulated endothelial cells, and has been found to oxidize several biological molecules and to nitrate free or protein tyrosine residues and other phenolics $(16,17)$. Thus, NO may become cytotoxic or cytostatic.

The higher cytotoxicity of resin-based sealers observed in this study confirms the findings of previous investigations $(5,6,18,19)$. The cytotoxicity of TopSeal can be due to minimum amounts of formaldehyde contained in this sealer or to the release of the amine and epoxy resin components from this material, as previously suggested (19). AHPlus has the same formulation of TopSeal. The urethane dimethacrylate (UDMA) in the structure of EndoREZ could be the responsible for its cytotoxic effect, as reported elsewhere (20).

In conclusion, Topseal presented the highest cytotoxicity among the tested sealers, releasing higher concentrations of $\mathrm{NO}$ and $\mathrm{H}_{2} \mathrm{O}_{2}$ in macrophage culture.

\section{RESUMO}

Este estudo avaliou in vitro a citotoxicidade de quatro cimentos obturadores (Topseal, EndoRez, TubliSeal e Kerr Pulp Canal SealerE.W.T) e seus efeitos na liberação de reativos intermediários do oxigênio e do nitrogênio em cultura de macrófagos peritoniais de ratos. Tioglicolato foi utlizado para se obter células peritoneias de camundongos. A cavidade peritoneal foi irrigada com $5 \mathrm{~mL}$ de solução salina $10 \mathrm{mM}$. As células foram lavadas duas vezes e foi feita uma suspensão $\left(10^{6}\right.$ células $\left./ \mathrm{mL}\right)$ em meio apropriado para cada um dos testes. A citotoxicidade dos cimentos foi determinada pela presença de peróxido de hidrogênio $\left(\mathrm{H}_{2} \mathrm{O}_{2}\right)$ e óxido nítrico (NO) pela oxidação peroxidase-dependente do vermelho fenol e pela reação de Griess, respectivamente. Suspensões de cimento foram obtidas em duas diferentes concentrações para cada material: $18 \mathrm{mg} / \mathrm{mL}$ e $9 \mathrm{mg} / \mathrm{mL}$, estabelecidas previamente pelo teste de viabilidade celular MTT. Comparando os cimentos, a liberação de $\mathrm{H}_{2} \mathrm{O}_{2}$ foi similar nas duas concentrações: Topseal > controle positivo (meio + células + Zimozan a $5 \mathrm{mg} / \mathrm{mL})>$ EndoRez $>$ TubliSeal > Kerr Pulp E.W.T. > controle negativo (meio + células). A liberação de NO na concentração de $9 \mathrm{mg} / \mathrm{mL}$ foi: $\mathrm{de} 9 \mathrm{mg} / \mathrm{mL}$ foi: controle positivo (meio + células + solução de LPS a 10 1/4g/mL) > Topseal $>$ Kerr Pulp E.W.T. $>$ TubliSeal $=$ EndoRez $>$ controle negativo (meio + células); e na concentração de $18 \mathrm{mg} / \mathrm{mL}$; e na concentração de $18 \mathrm{mg} / \mathrm{mL}$ : controle positivo > Topseal > Kerr Pulp E.W.T > TubliSeal > EndoRez > controle negativo. Baseado nos resultados, pode-se concluir que o Topseal apresentou a maior citotoxicidade dentre os cimentos avaliados, liberando as mais altas concentrações de $\mathrm{NO}$ e $\mathrm{H}_{2} \mathrm{O}_{2}$ em cultura de macrófagos.

\section{REFERENCES}

1. Torabinejad M, Ung B, Kettering JD. In vitro bacterial pen- etration of coronally unsealed endodontically treated teeth. J Endod 1990;16:566-569.

2. Williams DF. Biocompatibility: an overview. In: Encyclopaedia of Medical and Dental Materials. Williams DF, Oxford: Pergamon; 1990. p.51-59.

3. Geurtsen W, Leyhausen G. Biological aspects of root canal filling materials. Histocompatibility, cytotoxicity and mutagenicity. Clin Oral Investig 1997;1:5-11.

4. Schmaltz G, Hoffmann M, Weis K, Schweikl H. Influence of albumin and collagen on the cell mortality evoked by zinc oxide-eugenol in vitro. J Endod 2000;26:284-287.

5. Schweikl H, Schmalz G, Federlin M. Mutagenicity of the root canal sealer AHPlus in the Ames test. Clin Oral Invest 1998;2:125-129.

6. Eldeniz AU, Mustafa K, Orstavik D, Dahl JE. Cytotoxicity of new resin-, calcium hydroxide- and silicone-based root canal sealers on fibroblasts derived from human gingiva and L929 cell lines. Int Endod J 2007;40:329-337.

7. Forman HJ, Torres M. Redox signaling in macrophages. Molecular aspects of Medicine 2001;22:189-216.

8. Kayser O, Kolodziej H, Kiderlen AF. Immunomodulatory principles of Pelargonium sidoides. Phytother Res 2000;15:122-126.

9. McBride AG, Borutaité V, Brown GC. Superoxide dismutase and hydrogen peroxide cause rapid nitric oxide breakdown, peroxynitrite production and subsequent cell death. Biochim Biophys Acta 1999;1454:275-288.

10. Pick E, Mizel D. Rapid microassay of measurement of superoxide and hydrogen products. J Immun Meth 1981;46:211-226.

11. Green LC, Wagner DA, Glogowski J, Skipper PL, Wishnok JS, Tannenbaum SR. Analysis of nitrate, nitrite, and [15N] nitrate in biological fluids. Anal Biochem 1982;126:131-138.

12. Barile FA, Dierickx PJ, Kristen U. In vitro cytotoxicy testing for prediction of acute human toxicity. Cell BiolToxicol 1994;10:155-162.

13. Unanue ER. The regulation of lymphocyte functions by macrophage. Immunol Rev 1978;40:228-235.

14. Laskin DL, Laskin JD. Role of macrophages and inflammatory mediators in chemically induced toxicity. Toxicology 2001;160:111-118.

15. Ramasarma $\mathrm{T} . \mathrm{H} 2 \mathrm{O} 2$ has a role in cellular regulation. Indian $\mathrm{J}$ Biochem Biophys 1990;27:269-274.

16. Ischiropoulos H, Nelson J, Duran D, Al-Medhdi A. Reactions of nitric oxide and peroxynitrite with organic molecules and ferrihorseradish peroxidase: interference with the determination of hydrogen peroxide. Free Radic Biol Med 1996;20:373-381.

17. Linares E, Giorgio S, Mortara RA, Santos CXC, Yamada AT, Augusto O. Role of peroxynitrite in macrophage microbicidal mechanisms in vivo revealed by protein nitration and hydroxylation. Free Radic Biol Med 2001;30:1234-1242.

18. Bouillaguet S, Wataha JC, Lockwood PE, Galgano C, Golay A, Krejci I. Cytotoxicity and sealing properties of four classes of endodontic sealers evaluated by succinic dehydrogenase activity and confocal laser scanning microscopy. Eur J Oral Sci 2004;112:182-187.

19. Cohen BI, Pagnillo MK, Musikant BL, Deutsch AS. Formaldehyde from endodontic materials. Oral Health 1998;88:37-39.

20. Hikage S, Sato A, Suzuki S, Cox CF, Sakaguchi K. Cytotoxicity of dental resin monomers in the presence of S9 mix enzymes. Dent Mater J 1999;18:76-86.

Accepted March 31, 2008 